\title{
Musaraña barroca: análisis textual de La nada cotidiana de Zoé Valdés.
}

\author{
Baroque Shrew: Textual Analysis of La nada cotidiana \\ by Zoé Valdés.
}

\section{Resumen}

El presente trabajo de investigación analiza La nada cotidiana de la escritora cubana Zoé Valdés, partiendo del supuesto que una investigación como esta contribuye a conectar una producción cultural con la tradición literaria a la que pertenece, reconstruyendo el contexto del cual ha sido sacada la producción literaria por una crítica, basada en el mensaje político que esta trasmite. Además pretendemos abrir una de las puertas de entrada a la literatura latinoamericana como lo es el barroco latinoamericano, ya que como constante histórica sigue actualizándose en el neobarroco. Esta puerta de entrada nos parece imprescindible para aproximarnos a la literatura latinoamericana y entendiendo uno de sus orígenes poder explicarnos los derroteros actuales. La metodología del estudio es el uso de un enfoque desde la "historia de vida" como itinerario de lectura con una focalización en el yo lectora como un modo de evidenciar los componentes subjetivos en el análisis del texto.

Palabras claves

La nada cotidiana, Zoé Valdés, barroco latinoamericano, neobarroco.

\begin{abstract}
The following paper analyzes Zoé Valdés' novel La nada cotidiana under the assumption that this investigation may contribute to connecting this cultural product to the literary tradition it belongs to by reconstructing the context from which it has been removed by literary criticism biased against the political message of the novel. Furthermore, we aspire to open one of the doors to Latin American Literature, namely the Latin American Baroque,and its contemporary manifestation, the Neobaroque. This entrance way is deemed essential for understanding Latin American Literature and its origins, and by doing so we can penetrate
\end{abstract}


in its current directions. The life history method is used as reading itinerary with a focus point on the "she reader" as a way of demonstrating the subjective components with the analysis of the text.

Keywords

La nada cotidiana, Zoé Valdés, Latin American Baroque, Neobaroque.

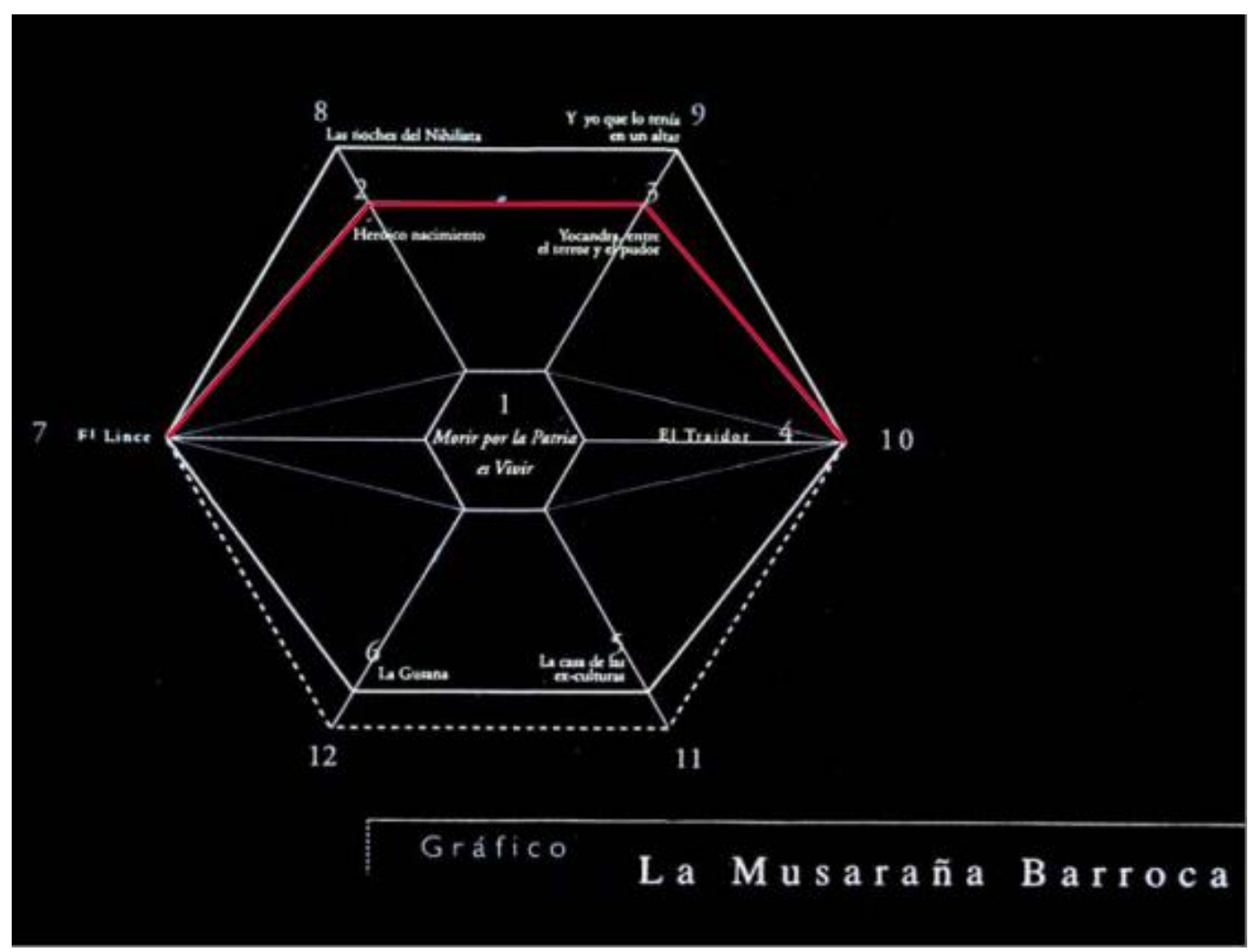

\section{Introducción}

Cuba posee una revolución y una condenada tradición literaria. Una tradición vital y mortífera, proliferante y devoradora. Hace dos años que recorro esa riquísima entrada cubana a la literatura latinoamericana, una entrada genuina que me permita observar la medianía existente en este Valle de Lágrimas. Comencé con Lezama y su Expresión Americana, esto me llevó a Martí y Nuestra América. Por fin encontraba ensayos vitales, llenos de poesía, no apegados al 
criterio de autoridad. Ensayos que respondían a un estilo de vida más que a investigaciones estériles. Dicen — Lezama siempre fue Lezama, casi no tuvo evolución como escritor-, todo estaba ahí en su poema Muerte de Narciso, leído por él en el patio de la universidad cuando tenía 18 años. Para qué hablar de Paradiso. No se puede hablar de esa novela-imagen, mejor leerla completa. No sé cuánto tiempo estuve pegada en las disquisiciones filosóficas de Cemí, Fronesis y Foción. Y ese Oppiano Licario que me envolvía y hacía que sentada en la biblioteca de mi universidad añorara esa otra que veía en el libro: una polémica interesante sobre las cosas esenciales de la vida. Empecé a atesorar la convicción de que muy lejos de aquí creadores habían creído en el concepto de "caldo de cultivo" y se habían empeñado en sentar bases culturales consistentes. Esa era mi América y mi Paradiso. Los creadores desde distintas áreas, formando una red. Leyendo en las universidades, sirviendo de paraguas para los más jóvenes. Intelectuales inclusivos y voluntariosos que se sacudían de la parálisis que les producía esa "instintiva desconfianza en nuestras capacidades". América sí podía crear, podía ser genuina. Luego me interné en la historia de la Revista Orígenes, en su unión, en la perseverancia de un grupo de amigos, en su catolicismo, en su neutralidad criticada por los medios intelectuales, en sus problemas económicos y en los esfuerzos para mantenerse por 12 años. Después tenía que abordar a Alejo Carpentier y Severo Sarduy. Leí Los Pasos Perdidos, perdiéndome para encontrarme y volver a perderme. Después de todo, la vida es perder. Y a Severo le seguí la pista en De Dónde son los Cantantes, pasando por Cobra, siguiendo por sus ensayos y su poesía. Ahí estaba el "barroco latinoamericano" y el "neobarroco" en todo su esplendor. La puerta de la literatura latinoamericana no había sido abierta, oficialmente, en la carrera que yo estudiaba. Recorrí el camino con un ramo optativo en la mano: "Cuerpo y poder en la literatura latinoamericana" y después continué sola.

Me obsesionaba la forma de la novela que estaba leyendo y su título $L a$ Nada Cotidiana y además había sido escrita por una escritora cubana: Zoé Valdés. Era un texto de 170 páginas, muy bien hecho y tenía una estructura que 
yo empezaba a olfatear. Una madrugada de 1998 y después que una profesora de la universidad me había hablado de "la figura en el tapiz" de Henry James, libro que yo no había leído. Me daba vuelta en la cabeza que eso era lo que yo veía: una figura en el tapiz o en la pared de mi habitación. Rueda de la historia. Rueda de bicicleta. Perla irregular. Rueca. Me asalta una figura en el tapiz, una musaraña barroca, una espacialización del discurso. Me asalta un gesto de salvación en la nada cotidiana. Esa figura de sueño iría tomando la forma de una Musaraña Barroca y de ahí saltaría al análisis textual del libro La Nada Cotidiana (LNC) ${ }^{1}$.

La musaraña es un animal pequeño y devorador, cuyo cuerpo mide $3 \mathrm{~cm}$, pudiendo medir 9 y llegando, en algunos casos, a medir $12 \mathrm{~cm}$. La musaraña es también un concepto definido en el texto por la protagonista, conformándolo todas aquellas meditaciones centradas en sus dos amantes: el nihilista y el traidor y todas aquellas nimiedades cotidianas. Tales musarañas estarán unidas a su insistente pedaleo en bicicleta, en su ida y vuelta al trabajo: la redacción de una revista. La protagonista de esta novela se llama Yocandra y su escritura surge desde su habitación hexagonal; desde ahí, un punto fijo como el eje de una rueda, relata todo lo que le sucederá durante un día de "período especial” en La Habana. Desde ese presente, que es el tercer capítulo, cuenta su historia, aludiendo a sus padres y amigos y construye todo el texto, inclusive un final que es puesto al principio como capítulo 1.

Este libro abre con el aforismo “¿Por qué algo mejor que nada?” del pensador Emile Ciorán. Este escritor nos va implacablemente despojando de todos aquellos pretextos que tenemos para vivir: estudios, familia, pareja, ropajes de esta sociedad para tenernos controlados. Tantas veces hemos apostado al algo y desechado la nada. Esta pregunta nos permite despertar a los capítulos que se despliegan a continuación, convirtiéndolos en una respuesta posible. Se hace evidente el sueño de totalidad, el presente intemporal que configura una sentencia breve. La dedicatoria "A mi hija Attys Luna que nació en periodo especial” remite

\footnotetext{
${ }^{1}$ Citaremos la novela objeto de nuestro estudio: LNC.
} 
al tiempo histórico declarado en 1991 por el régimen de Castro para afrontar el hundimiento del comunismo en Europa Oriental y que significó para Cuba la pérdida del $80 \%$ de intercambios comerciales y la suspensión de la subvención soviética (5000 millones de dólares anuales) con el consiguiente brutal desabastecimiento. El aforismo nos sitúa en un presente intemporal y la dedicatoria en un tiempo histórico. Dialéctica entre lo abstracto y lo concreto, tomando en cuenta que LNC se publicó en 1995.

El capítulo 1: "Morir por la patria es vivir" está titulado con esta consigna política y tiene varias señales que nos hacen diferenciarlo del resto de los capítulos de la novela. La letra cursiva responde a la tradición testimonial, pero la diferencia más evidente con el resto de la novela es su cosmovisión míticopoética, ya que tiene un evidente correlato bíblico, específicamente la Lucha con el Ángel (Génesis 32, 23-32), relato que según Barthes corresponde a la tradición oral. Consiste básicamente en que cuando estamos a punto de entrar en la tierra prometida, Dios nos viene a probar y solo cuando el elegido llega al extremo de sus fuerzas podría tener éxito. Este golpe de Dios nos deja heridos para siempre. La elegida es un "ella", pronombre que marca una "máxima vacuidad referencial", es decir, cualquier mujer. Este capítulo reformula la lucha con el ángel y así actúa la repetición como un mecanismo estructural de la producción de textos, acentuado por el orden de la repetición que irá al comienzo y al final de la novela. La lucha con el ángel es una lucha por conservar la memoria, por no olvidar, por eso "ella" se enfrentará con una primera modulación angélica: un querubín, luego con un ángel rubio y seductor del cual se enamora y finalmente con el ángel de la nada que es el que decide y que sitúa a ese ella en un lugar -el purgatorio- y le señala que, como no es lo suficientemente culpable para irse al Infierno ni lo suficientemente inocente para ir al Paraíso, la devolverá a la Isla.

Este primer capítulo es un centro irradiador lezamaniano, fuerte imagen poética, surgida como síntesis de la memoria en el final del capítulo 9 que es colocado al principio de esta novela como impulso generador de toda ella. Con ello el narrador hace que el lector asista a una ruptura temporal del relato, 
prolepsis que nos hace conscientes de que lo que se narra primero no necesariamente ocurrió primero en el tiempo de la historia y que puede haber ocurrido al final, como en este caso, y que se hace imprescindible el paso de lo irreal a lo histórico, de la imagen a la historia, de lo concreto a lo abstracto y a lo concreto de nuevo: plenitud del conocimiento poético.

El enunciado ella viene de una isla que quiso construir el paraíso pero... termina y comienza LNC y con ello configura una "estética de la repetición”, ya que en el capítulo 1 y en el resto de los capítulos observamos dos historias personales análogas: una contada desde un punto de vista mítico-poético y la otra fuertemente unida a la historia cubana. El capítulo 1, por lo tanto, es una "variable independiente" que permite que el texto al pasar de un estado a otro se reformule, haciendo pensar al lector a través de este simulacro que la voz narrativa anulará la historia, sin embargo, en el capítulo 2 la narración en primera persona revaloriza la historia personal de este "ella" y la extiende a la historia de la patria cubana.

Así llegamos al "Nacimiento heroico", ya que el capítulo 2 tiene claros referentes históricos y está construido por un narrador en primera persona -protagonista de la novela- que, a través de un "cuenta mi madre", que nos remite según la historiadora Sonia Montecinos a una historia construida en la tradición oral femenina, se hace nacer al interior del texto, siendo nombrada Patria por su padre, pues nace el 2 de mayo de 1959, el año de la revolución cubana. Así su padre pasará a ser el padre de la Patria. Con lo anterior asistimos a personajes arquetípicos, es decir, todos tienen un presente en la novela y otro, en el paradigma político-cultural. Son personajes referenciales, huellas que nos remite a que el autor ha optado por el enfrentamiento entre nuestro conocimiento previo del personaje con las expectativas que genera y la realización del personaje en la novela.

Comienza acá la verdadera musaraña, ya que en el capítulo 3, "Yocandra entre el terror y el pudor", marca el tiempo presente que sitúa a la protagonista en una habitación hexagonal desde donde empieza a escribir. Así surge el traidor que confirmará un capítulo 4 y que es definido como el escritor de moda, el primer 
amor de la protagonista y el que la marca. Primero porque la obliga a cambiar el nombre de Patria por Yocandra y también a perder la virginidad. Se convierte en su empleada, aprendiz y secretaria personal y se casa con él, se va a Europa y aquí se da cuenta que él se traiciona a sí mismo, escribiendo un libro que solo consignaba "no puedo escribir porque me persiguen". Lo abandona y se vuelve a Cuba. Sin embargo, con el tiempo alterna sus deseos entre su antiguo amor, el traidor, y el nihilista, su nuevo amante. El traidor cambia solo físicamente en la novela, porque espiritualmente sigue escribiendo libros que nunca se publicarán.

"La Casa de las ex-culturas", el capítulo 5, funciona como referente estético, consignando la iniciación sexual de Patria, hablándonos de cómo su madre Aída se transformó en la Ida y cómo su padre, de sindicalista se transforma en un loco. Esta casa que se la ha dado el partido fue de un gusano que vive en Miami y que convirtió su casa en museo. Con este capítulo, Yocandra señala que la Cuba culta revolucionaria se ha ido y se ha convertido en una casa de las exculturas, aludiendo a Casa de las Américas, principal organismo cultural creado por la revolución en 1959.

Los capítulos 6 y 7 confirman las amistades de Yocandra con la Gusana y el Lince. La primera ha escrito mostrando cómo se ha traicionado y el segundo la ha llamado por teléfono. Ambos animan a la protagonista a escribir y Yocandra señala que siente que los han obligado a vivir desperdigados por el mundo. El Lince es asimilado a Martí, un Guerrero Heroico que en medio de los bárbaros y solo con poesía, levanta una Casa de la Cultura. Leamos a Cavafis:

¿Por qué empieza de pronto este desconcierto

Y confusión? (¡Qué graves se han vuelto los rostros!)

¿Por qué calles y plazas aprisa vacían

Y todos vuelven a sus casas compungidos? 
Porque se hizo de noche y los bárbaros no llegaron.

Algunos han venido de las fronteras

Y contado que los bárbaros no existen.

¿Y qué va a ser de nosotros ahora sin los bárbaros?

Esta gente, al fin y al cabo, era una solución.

El otro siempre como el bárbaro inventado por nuestro miedo. Si seguimos, el capítulo 8 configura el segundo amante de Yocandra: el Nihilista. Este capítulo es un homenaje al octavo capítulo, fuertemente erótico, de la novela imagen Paradiso de José Lezama Lima. Y en el capítulo 9, "Y yo que lo tenía en un altar", ya terminando la noche, a Yocandra se le juntan sus dos amantes y le señala al Traidor por qué le coloca ese nombre: no porque la haya traicionado a ella, sino porque vive traicionándose a sí mismo. Sale a botar la basura y una señora dice: “y yo que lo tenía en un altar" en una evidente alusión a Castro; otras señoras la miran para culparla. Así Yocandra se sienta en su cama observando el mar a través de sus tres ventanas. Aquí se puede apreciar el "yo" de la escritura, el “yo" narrador y el "yo" personaje que al ser una careta de la sobrevivencia es un no-yo, pero así se manifiesta: pide a sus orishas y empieza "ella viene de una isla que quiso construir el paraíso, pero al final terminó construyendo un infierno..."

Estoy convencida que la estructura de LNC responde a una poética lezamaniana. El capítulo se vuelve una metáfora del texto, en un centro irradiador que es un final que siempre irá adelante. La poesía siempre irá adelante decía Rimbaud y será la que haga el enlace entre historia y cultura, como decía Lezama. Podemos deducir que hay tres niveles del discurso textual, un nivel fuera de serie que debe ir adelante como anticipador, profetizando todo lo que viene, pero que se vuelve insuficiente para dar cuenta de la realidad y por eso la escritora debe recurrir a su historia personal, que sería un segundo nivel, "lo narrado" (el enunciado), y un tercer nivel que sería cómo muestro lo narrado, cómo construyo 
el artificio y que sería el nivel de la enunciación o de la escritura. Poesía e historia nutren la escritura que se convierte en la diégesis entre "lo narrado" y cómo compongo lo narrado, es decir, cómo articulo un discurso. Historia colectiva y personal que a través de la poiesis o de la creación se convierte en escritura.

Desde una organización geométrica y con límites precisos: la Musaraña Barroca y con un centro desde donde parte la escritura, Zoé Valdés construye un sistema excesivo. Son justamente estos límites los que permitirán crear "un orden en el desorden" como se ha caracterizado al barroco. El cuerpo geométrico se transforma en el límite que permite asegurar que la autora no renuncie a contar una historia y el exceso sea contar la historia así como la contó. Valdés coloca a Yocandra en un espacio intermedio, un paraíso infernal. Sabe que en este espacio la memoria individual de Yocandra no existe y, por lo tanto, no existen las consecuencias que ésta ha sufrido por vivir un determinado momento histórico. Por eso, crea otro espacio: una habitación hexagonal, su propia isla desde la cual pueda contar su historia personal y subvertir el mito compartido de que Cuba es libertad.

\section{La Lucha con el Ángel}

El texto La Nada Cotidiana es abierto por el pre-texto: $P$ Por qué algo mejor que nada?, un aforismo o sentencia breve del pensador E.M. Cioran. Este último es definido por Fernando Savater como "un místico sin dogmas y creencias, sin dioses, empeñado en hacernos despertar -en despertar el mismo- de todas las ilusiones que facilitan nuestra vida." Agregando que Cioran nos va despojando de todas nuestras convicciones y el resultado de esto no es el agobio, sino "una ligereza que nos hace sentirnos absurdamente vivos más allá de todas nuestras razones para vivir" $(25) .^{2}$

\footnotetext{
${ }^{2}$ Fernando Savater. Hetedoxia y Contracultura. Barcelona: Montesinos Editor, 1982. p. 25.
} 
Utilizando lo anterior como antecedente, podemos señalar que este aforismo o "forma breve" nos permite despertar, a través de la interrogación, a los 8 capítulos que se despliegan a continuación, convirtiéndolos en una de las respuestas posibles. En este sentido, se nos hace evidente el "sueño de totalidad o de infinitud" del aforismo que al configurar "un presente intemporal" niega el tiempo lineal, transformándose en un "fragmento que evoca un pasado del cual sería el comienzo" (Pelegrin 40). Fragmento que remite a un todo que es el comienzo, es decir, un primer capítulo que condensará los 8 capítulos restantes.

Por otro lado, Zoé Valdés dedica La Nada Cotidiana a su hija Attys Luna “que nació en periodo especial". Dicho periodo fue declarado desde 1991 por el régimen Castrista para afrontar el hundimiento del comunismo en Europa Oriental, lo que significó para Cuba la pérdida del $80 \%$ de sus intercambios comerciales y la supresión de las subvenciones soviéticas (unos 5000 millones de dólares anuales). Debido a lo anterior, el gobierno cubano redujo la dieta de racionamiento, ya insuficiente para la supervivencia, y cercenó los programas sociales, llevados a cabo en hospitales, escuelas, defensa y jubilación. Si tomamos en cuenta que la LNC se publica en 1995.

Podemos señalar que la dedicatoria, al contrario que el aforismo utilizado como pretexto, nos remite a un tiempo histórico real en el que se desarrollará dicha novela. Un "periodo especial", declarado por el gobierno cubano y caracterizado por un brutal desabastecimiento que incidirá dramáticamente en la novela que analizamos.

El universo diegético de LNC comienza con capítulo 1, titulado con una consigna política Morir por la Patria es vivir y posee varias señales que nos hacen diferenciarlo del resto de los capítulos de la novela que estudiamos. Una de ellas — la más evidente - es su tipografía distinta: una letra cursiva que corresponde a la tradición testimonial. Pero la diferencia más importante con el resto de los capítulos es su cosmovisión mítico- poética, construida sin marcas 
referenciales históricas, por un narrador externo o ajeno a la fábula que focaliza a un ella pronombre que desde la perspectiva del personaje marca una "máxima vacuidad referencial" (Pimentel 68). Este narrador omnisciente nos señala:

Ella viene de una isla que quiso construir el paraíso. El fuego de la agresividad devora su rostro. Los ojos casi siempre húmedos, la boca suplicante como la de una estatua de bronce, la nariz afilada. Ella es como cualquier mujer, salvo que abre los ojos a la manera de las mujeres que habitan las islas: hay una tranquila indiferencia en sus párpados. También tiene el cuerpo tenso, en contradicción con sus pupilas demasiado fluidas. No es verdaderamente bella, pero tiene algo no sabríamos qué, quizás un rictus de ironía o bien un miedo extraordinario. Ella no cambia nunca, no cambiará. Morirá joven y con todos sus deseos. (Valdés 15)

Desde el principio, la configuración del personaje femenino, impulso generador y natural, nos remitirá a la protagonista de esta novela y a su madre y a la misma autora Zoé Valdés, siendo fundamental el hecho que este ella viene de una isla que quiso construir el paraíso y eso ya la singulariza respecto a las demás mujeres, por lo tanto, si bien el narrador nos advierte que no es verdaderamente bella, invoca un código fundador de la belleza y la perfección como lo es la mitología para caracterizarla, señalándonos que ella no cambia nunca y no cambiará y que morirá joven y con todos sus deseos.

Este ella transformada en una diosa se enfrentará a un personaje perteneciente a la mitología cristiana: el Ángel de la Nada, la tercera modulación angélica después de un querubín y un ángel rubio y seductor. Este enfrentamiento nos remite al relato bíblico La lucha con el ángel (Génesis 32. 23-32), relato mítico que según el parecer de Roland Barthes, ha podido venir a la escritura por una tradición oral y consiste básicamente en el hecho que cuando estamos por entrar a la Tierra Prometida, Dios nos viene a probar (112). Sea cual sea el golpe 
o el percance o la crisis que atravesamos nos deja heridos y como extranjeros en este mundo. En este caso, Dios promete el éxito, pero no lo dará antes que el elegido haya llegado al extremo de sus fuerzas.

Por lo tanto, estamos ante una prueba o un juicio donde la elegida de Dios luchará con su memoria contra el olvido, representado por el Ángel de la Nada. En esta lucha será fundamental todo aquello que le permita a este ella recordar su historia. Lo primero que le permite recordar es su sexo femenino y, por lo tanto, su cuerpo de hembra que ha tenido hijos, luego el amor, después el pasado y los sentimientos naturales: la frescura del viento, un beso sobre los labios, la amistad, la canción, una risa. Dentro de este contexto, este ella tiene tres encuentros, el primero de ellos con un Querubín que le pregunta por su nombre, pero ella no responde. Ella al olvidar su nombre configura la primera pérdida de sí misma, ya que renuncia a su individualidad e identidad. El narrador siendo consecuente con esta pérdida hace que los contornos nítidos del tiempo y el espacio se pierdan y por lo mismo alrededor del cuerpo de ella el espacio se transforma en nube blanca y ésta al sentir que sus piernas no existen duda de su propia existencia. Tiene hambre y nada que comer y entonces recuerda que:

En su isla, cada parte del cuerpo debía aprender a resistir. El sacrificio era la escena cotidiana, como la nada. Morir y vivir: el mismo verbo, como por ejemplo reír. Sólo que se reía para no morir a causa de exceso de vida obligatoria. (Valdés 16)

Ella es un cuerpo resistente y por azar encuentra un espejo redondo y refleja su sexo en el azogue, comprobando que es una hembra y por una pequeña cicatriz de seis puntos entre la vulva y el ano recuerda haber tenido hijos, pero no sabe cuántos porque su memoria se ha transformado en un gigantesco jardín de péndulos cuyas campanadas le impiden que tenga recuerdos. La cicatriz nos permite relacionar a este ella con Aída, la madre de la protagonista de LNC, con lo cual este ella si bien está vacío de toda referencialidad se vuelve genérico. Así, 
la memoria de todas las mujeres llena de instantes de fugas y vacíos, se vuelve tan confusa como el entorno en que se encuentra este cuerpo femenino. En ese momento ella cree que debe partir y:

pierde las fuerzas... Siempre habrá que partir y perder la fuerza, la esperanza .... Perderse.... Nosotros mismos ... Uno debe partir... Allá habrá eternamente un sitio, un país que nos espera .... Una nada que nos espera... Una nada enternecedora. (Valdés 17)

El segundo encuentro es con un Ángel rubio y seductor que se acerca a ella levitando y le habla. Por supuesto que ella enseguida se enamora y, por lo tanto, vuelve a ser una chica confundida ante el primer desconocido. Ella, al contrario del primer encuentro, entabla un diálogo con este Ángel, a través del cual se evidencia el enfrentamiento entre estos dos personajes, ya que al preguntarle el Ángel si cayó ahí por accidente ella le señala que no le gusta esa palabra y que cayó ahí por azar. Entonces el Ángel afirmará que el azar no existe y que ella debiera desconfiar de todos los discursos antiguos, ya que es mejor parecer ignorante que nostálgico. Ella confundida le pregunta a que se refiere y él responde que se refiere a todas las criaturas que iguales a ella son inocentes y culpables a la vez. Y le define el Ángel el universo como una suerte de desgarramiento radical, donde no se puede ser una cosa y otra a la vez, ya que hay que ser prudente.

A pesar de que ella no entiende nada de lo que le ha dicho el Ángel. No bien comienza a reflexionar sobre la oscuridad de su pasado, el Ángel cae fulminado por un rayo de oro. Así empieza a terminar este segundo encuentro:

Ella está completamente desnuda y no siente vergüenza. Frágil pájaro moribundo, sabe que su infancia está enterrada muy lejos, en el hondo de sí misma, y constata que no ha envejecido. Está en el medio, en el justo 
medio de las edades, de los números, en lo inexplicable. Enfrente reposa el misterio, detrás las tinieblas. No es la noche la que va cayendo. Es el silencio. El sonido ensordecedor del silencio. Su letanía, dando la impresión de que es la noche. (Valdés 18)

El narrador al señalarnos que ella está en el justo medio de las edades, vuelve a relacionar este cuerpo femenino con la protagonista y la autora de la novela que analizamos que sabemos tiene treintaitantos años y que deberá superar el silencio de la noche para decidirse a escribir su historia. Sin embargo, a este ella le queda todavía el más terrible enfrentamiento y por eso busca un rostro en el follaje, pero no hay nadie solamente una carcajada y sostiene su tercer encuentro, entablando un diálogo más extenso con esta tercera modulación angélica. Reproducimos íntegramente este diálogo por parecemos fundamental en el análisis de la novela en estudio.

— ¿Hay alguien? -tiembla

— ¡Sí, por supuesto que hay alguien, usted! -responde la Nada.

Ella busca todavía endemoniada.-!No busque más! ¡Existo y no existo¿Hay alguien? - tiembla.

- ¿Y con quién tengo el honor de hablar? - Ella se hace la valiente-, ¿Quién es usted?

—Yo soy yo. Yo soy ese que soy. ¡El que decide! - exclama la Nada Ella piensa que siempre hay, en todas partes, ese "que decide". Y que nunca ha sido ella, precisamente, quien ha decidido por sí misma.

—Estoy aquí para explicarle la razón por la cual debe usted partir.

Vacila, no quiere saber. No le gusta conocer, porque conocer para ella significa abrir brutalmente una cicatriz.

—Y bien. Estamos en el Purgatorio. Usted está muerta. Y nosotros, los que decidimos, tenemos un grave problema con usted. Pues tiene 
cincuenta puntos para entrar en el Paraíso y cincuenta puntos para ganarse el Infierno. Su alma es demasiado inocente para obtener el Infierno y fue lo suficiente malvada para no merecer el Paraíso. No podemos permitirle una estancia interminable en el Purgatorio... Entonces...

— ¿Entonces, qué? -Tiene fiebre. Quiere discutir pero no logra estallar. Pierde fuerzas.

—Entonces soy yo quien decide... - La voz de la Nada penetra en ella. (19)

El narrador por fin se decide a dar a conocer el lugar y el estado en que se encuentra este ella. Está muerta y se encuentra en el mítico y literario: Purgatorio, espacio intermedio y de penitencia, un necesario paso para acceder al Paraíso. Ella es inocente y culpable, no es prudente, no es una cosa o la otra es ambas a la vez y por eso no puede ir al Paraíso o al Infierno. Como ella no ha decidido nunca por sí misma, la voz de la Nada la obliga, a través de un rayo dorado que hiere sus ojos, su cuerpo desnudo y su espíritu: mitad sereno, mitad impetuoso, a volver a su isla, esa isla que, queriendo construir el paraíso, ha creado un infierno. Ella no sabe qué hacer y por eso termina interrogándose: “¿Para qué nadar? ¿Para qué ahogarse?". El capítulo 1 responde a una poética Lezamiana, ya que la imagen poética surgida como síntesis de la memoria en el final del capítulo 9 es colocada al principio de LNC, anticipando un final que se transforma en un centro irradiador de toda la novela. Con ello el narrador a través de una ruptura temporal en el relato, llamada "prolepsis" (Pimentel 40) nos hace conscientes de que lo que se narra primero no necesariamente ocurrió primero en el tiempo de la historia y que se hace imprescindible en la construcción de la novela el paso de lo irreal a lo histórico, de lo invisible a lo visible, "de la imagen al hecho a la historia que indica precisamente la plenitud del conocimiento poético" (Vitier 141). Recordemos que para Lezama el poema es un cuerpo resistente, un tiempo 
original, un verdadero principio que realiza el enlace entre historia y cultura. Al respecto, Cintio Vitier nos señala:

En la visión de Lezama, la cultura universal es ofrecida por primera vez al americano como una fiesta o como tragedia: ambos contenidos se funden en el distanciamiento doloroso de su voluptuosidad. Pero no se trata del disfrute de un banquete que no hemos merecido, sino sacar a la cultura de su fríos encadenamientos aparentes, de su cerrazón de hecho consumado (pues quien dice cultura dice historia), para hacerla entrar en el impulso perennemente generador del sentido poético. Esto sólo será posible si encontramos el enlace, en un punto común que encierre la virtud germinativa original de ambas esferas: historia o cultura de un lado del otro poesía. Este punto medio y esa fuerza germinal totalizadora los halla Lezama en la imagen: "la imagen como absoluto, la imagen que se sabe imagen, la imagen como las últimas de las historias posibles". Hallado ese centro de gravitación, todo empieza a girar en torno a él. Un dato histórico, un sucedido, una escena, una interpretación de la cultura o una leyenda, pasado su escasísimo tiempo de vigencia causalista y factual, sólo puede vivir como imagen. (68)

El capítulo 1 se convierte en un centro de gravitación y, por lo tanto, todos los demás capítulos empezarán a girar en torno a él. Al respecto, señala Bachelard "la vida no comienza tanto lanzándose, como girando", (Bachelard 141) por eso este capítulo comienza a construirse al final de la novela, pero es un verdadero principio que servirá de enlace con el doble nacimiento de la historia personal y colectiva del capítulo que viene.

El texto LNC comienza y termina con el mismo enunciado "Ella viene de una isla que quiso construir el paraíso", configurando una "estética de la repetición" (Calebrase 45) a nivel estructural, ya que en el capítulo 1 y en el resto de los capítulos hay dos historias personales análogas. Así la voz narrativa es 
atada esta historia desde dos puntos de vista, uno poético-mítico y el otro fuertemente unido al correlato histórico cubano. Por lo tanto, el primer capítulo se vuelve en "variable independiente" que permite que al pasar el texto de un estado a otro se reformule la historia y se fragmenten los componentes del texto. Esto configura en un simulacro donde la voz narrativa en tercera persona hace un uso temerario del pasado, haciendo pensar al lector que va a asistir a la anulación de la historia, sin embargo a partir del segundo capítulo la narración en primera persona entra de lleno en la revalorización de su historia personal que es también la historia de Cuba.

Observamos que hay en el texto una operación de detallar la historia personal de un ella protagonista, esta operación hace que entero y parte estén copresentes. La marca de la enunciación explícita es el yo-aquí-ahora, es decir, la protagonista cuenta la historia durante un día de su vida desde una habitación hexagonal, configurando la musaraña barroca. Dentro de esto, el primer capítulo es un fragmento que implica un fractura en el discurso, es decir, una potencial ruptura, ya que este capítulo no contempla la presencia del entero y se constituye en forma autónoma. Esta práctica de carácter inductiva requiere de la indagación por parte de un lector que debe buscar la relación entre el primer capítulo y el resto del texto.

\section{Nacimiento}

El capítulo 2 lleva el título "Heroico Nacimiento" y desde aquí en adelante nos conectamos con un discurso que tiene claros referentes históricos, construido desde la perspectiva de un narrador en primera persona, focalizado sistemáticamente en la protagonista de la novela: Patria. Este narrador si bien no puede focalizar más que su propia conciencia, tiene, sin embargo, "la opción de cambiar la perspectiva temporal y cognitiva, desplazándose en el tiempo, 
ubicándose en distintos momentos de su devenir existencial como persona". (Pimentel 109). Esto implica que Patria accederá a un manejo preferencia! de la historia $^{3}$ y que ayudada por lo que le cuenta su madre desplazará el "yo" que narra (Yocandra) desde un tiempo presente a un tiempo pasado: el momento del nacimiento del "yo" narrado (Patria).

Si tenemos en cuenta que según Sonia Montecinos este "Cuenta mi madre" (Valdés 21) nos remite a una historia pasada construida en la tradición oral femenina y que, de este modo, el habitar de la mujer en el reino de la oralidad expresa su posición genérica y coloca al universo de la intimidad como referente que resiste al vacío. Tendremos como resultado un testimonio que da origen a un discurso autobiográfico, ya que "esa nada, que remite a la angustia y choca con la pregunta por el sentido, va a ser ocupada por la experiencia ontológica femenina: su cuerpo, su sexo, su relación con el hombre, con los hijos, con lo sagrado" (Montecinos 121).

El empleo del referente histórico adquiere un tratamiento preferencial en esta novela al situar el nacimiento de Patria en el año 1959, el mismo año en que nace la Patria cubana en manos de la revolución triunfante y al hacer arrancar la historia desde la Plaza de la Revolución y durante el discurso de Fidel Castro. Sin embargo, la estremecedora parición de Patria surge de lo que la madre de la protagonista cuenta a su hija y, por lo tanto, asistimos al doble nacimiento de: un “yo" narrado (Patria) y un "yo" que narra (Yocandra). Aída le ha contado a su hija que esta comenzó a "cabecearle la pelvis, a romperle los huesos", "dando cabezazos, codazos, tortazos, queriendo huir de su cuerpo, de todas partes" y que antes de salir de la concentración multitudinaria el Che le pondría simbólicamente una bandera cubana en su barriga.

3 Tomo la noción de historia como la concibe Luz Aurora Pimentel "como una serie de acontecimientos interrelacionados y no como ocurrencias aisladas, [y por lo tanto] la serie acusa una doble organización temporal: por una parte se ordenan los eventos serialmente en una cronología; por otra, no proliferan arbitraria o indefinidamente, sino que están configurados por un principio de selección orientada que busca una finalidad, una totalidad significante" (19). 
Agregando que su cuerpo se anunciaba como nunca, en otra dimensión, "alternando entre lo microscópico y lo macroscópico" y que a pesar de estar a un paso del latido de la nada, sentía mucha vida dentro. Saboreó el dolor de la espera y al llegar su esposo que lo habían ido a buscar a la zafra, se acurrucó junto a su barriga y casi se desmaya de orgullo cuando se enteró que el Che le había puesto a su mujer la bandera en la barriga. Ella aunque era valiente no hubiera podido enfrentarlo sola. Luego fue llevada a un saloncito lúgubre, donde Elena Luz, la doctora guerrillera, le apuró el parto. Así el narrador describe tal experiencia:

Ella iba del sillón gris a la cama y viceversa, en repetidas ocasiones. Los médicos le pidieron que pujara. Ella no quería desmayarse. Las manos ajenas volvieron abrir su vulva y se pasearon de un lado a otro. Su vulva era como el cuello de tortuga de un suéter de invierno. Ella se derramó en sangre por la vulva, por el clítoris, por el ano, orinó, vació sus intestinos. Exponía el cuerpo abierto y las entrañas exploradas a la mediocridad rutinaria que descubrió en las miradas de los doctores. [...] Le pincharon el otro brazo. De nuevo el trasteo feroz en su interior y los dolores inenarrables. Según los expertos estaba a punto de parir, según ella se moría, se vaciaba. (Valdés 24)

A través del parto se entrelaza la vida y la muerte y en el tercer pujo, el de la fuerza, el que la hizo a una madre y a la otra hija, nace un dos de Mayo la protagonista de esta historia. Reflexionando sobre el momento de su nacimiento y el momento presente desde el que escribe, Yocandra nos señala: "Estaba ajena de mí. Aún sigo ajena de mí. Mi madre dejó de ser yo. Yo dejé de ser ella. [...] Yo fuera de su universo, inicio el mío. Para ella terminó el dolor. Para mí acaba de comenzar" (25).

Apenas nació esta bebita su padre empezó a reprocharle a ella y su madre que no hubiera nacido el 1 de Mayo, el Día de los Trabajadores de la Revolución triunfante y aunque no dejaba de lamentarse, al decidir ponerle a su hija Patria y 
convertirse él en el Padre de la Patria solloza creyéndose glorioso. El acontecer de LNC se sitúa en una fluencia tempo-espacial y psicológica viables (de vida). Todos los personajes contienen un potencial arquetípico, casi tode s tienen una dimensión en el presente de la novela y otra en el tiempo del paradigma políticocultural, por lo tanto la novela opta por "personajes referenciales". Al respecto, Mieke Bal señala:

Todos estos personajes que podríamos denominar referenciales, a causa de su evidente correspondencia con un marco de referencia, actúan según el modelo que conocemos previamente. O no. En ambos casos la imagen que recibimos de ellos está determinada en gran medida por el enfrentamiento entre nuestro conocimiento previo y las esperanzas que éste crea, por una parte, y la realización del personaje en la narración por la otra. Optar por un personaje referencia! significa, en ese sentido, optar por ese enfrentamiento. (91)

\section{Musaraña}

En el Capítulo 3, titulado "Yocandra, entre el terror y el pudor" el narrador nos sitúa en este "cataclismo de interrogantes" que es el tiempo presente y desde "una habitación o refugio hexagonal" construye el discurso autobiográfico que va articulando LNC. Yocandra está sentada en su cama, observando el mar a través de sus tres ventanas abiertas confirman que el mar existe. Desde aquí ella reflexiona o piensa en musarañas. Por eso si unimos el centro de la habitación con estas tres ventanas, logramos hacer los radios de esta telaraña, musaraña, rueda de bicicleta o perla irregular. Con lo que asistimos a la prioridad que le otorga el narrador a mostrar el proceso de construcción de la obra y como la materialidad del lenguaje al incurrir en un furor autoreferencial espacializa el discurso. Por eso, 
se nos hizo necesario construir el gráfico: Musaraña Barroca ${ }^{4}$ para dar cuenta de la dimensión espacial y temporal de LNC.

Yocandra hace infinitos amaneceres que realiza esta "ceremonia matinal" en la que no solo toma café sino que se somete a muchas preguntas y al palpar la vida segundo a segundo realiza un doble ejercicio: físico y mental. Yocandra sabe que dentro de ella al igual que en cada sitio de la tierra se rompió el equilibrio. Desayuna agua con azúcar prieta y la cuarta parte de los ochenta gramos del pan de ayer. Señalándonos:

He administrado muy bien el pan nuestro de cada día. Cuando hay - ¡si es que hay!- lo pico en cuatro: un pedazo en la hora de almuerzo, otro en la comida, el tercero antes de acostarme, si no lo he compartido antes cuando tengo visita, y el cuarto es destinado al desayuno. (Valdés 29)

Con el antecedente anterior, nos damos cuenta el terrible desabastecimiento que afecta a Yocandra, sin embargo ella todos los días se viste y al mirarse al espejo se siente como siempre "lista para la batalla", luego saca su bicicleta y cuando toca apagón baja los ocho pisos por la escalera con el vehículo a cuestas. Estando en la calle, pedalea como cada mañana, pensando en las “musarañas", hacia su oficina: "EL TRABAJO”. Trabaja como jefa de redacción de una revista de literatura que no puede realizarse por "los problemas materiales que enfrenta el país, el periodo especial y todo lo que sabemos que estamos sufriendo y lo que nos queda por sufrir". Almuerza un trocito de pan, la mitad de un plátano y se toma su agua de azúcar prieta. Está hasta las 14:00 hrs. en la oficina, "porque ya en ningún lugar se trabaja hasta las cinco". Regresa a su casa en bicicleta y al pedalear piensa en lo de siempre: las musarañas. Llega a la casa y no hay luz, intenta cocinar y en el mejor de los casos termina como las ocho o nueve, porque el gas va y viene. Se baña y para eso carga agua de la esquina,

\footnotetext{
${ }^{4}$ Véase el gráfico "La Musaraña Barroca" que inicia este artículo.
} 
subiendo la escalera con los cubos tres o cuatro veces. Esto hace todos los días que no la visitan el Traidor o el Nihilista.

La noción "musarañas” es definida por Yocandra en LNC, señalándonos que pensar en ellas es "pensar en ellos [el Traidor y el Nihilista] o repasar como ahora los argumentos cotidianos de mi existencia" (31), por lo tanto, las "musarañas" concretan el principio neobarroco Calabresiano: Ritmo y Repetición, ${ }^{5}$ ya que lo que permite construir la trama de la novela que estudiamos es el hecho que el narrador realice sistemáticamente esta acción: pensar en sus dos amantes o repasar todo lo que le pasa en su vida cotidiana.

En tono de confidencia, Yocandra nos señala: "Anoche en mi cama durmió un traidor, anteanoche un nihilista” y se pregunta “¿Cuánto hace que vivo esta pasión agotadora de alternar mis deseos?” (28). En este capítulo el narrador comienza a configurar un personaje clave en LNC: El Traidor, que al burlarse del nombre de la protagonista, señalando que él no podía acostarse con la Patria, provoca el cambio de su nombre por el de Yocandra, con el consiguiente surgimiento de la narración autorial.

Patria "contaba dieciséis años y aspiraba muy en secreto a ser una escritora de renombre universal. Él tenía treinta y tres y decía que había publicado dos novelas, tres libros de ensayo y un libro de poesía. Era el escritor de moda". Patria lee el libro de poesía del Traidor, llamado Los versos de Yocandra, "una obra maestra de la literatura cubana" y después de sentir celos, inmediatamente quiso ser "aquella mujer que tanto amor y dolor había inspirado en aquel sabio", entonces se decide a cambiar su nombre. Yocandra es un nombre literario que contrae un elemento femenino: un yo (ella) con un elemento masculino femenizado: andra; alude, también, a un Yocasta, personaje que en la tragedia clásica Edipo Rey encarna el escepticismo, al señalar que el hombre no debía estar sujeto al miedo, ya que al estar gobernado por las cosas del azar no tiene presencia clara de ninguna cosa. Por eso para Yocasta es mejor vivir a la aventura,

${ }^{5}$ Véase lo que señala Calabrese a propósito a la "estética de la repetición" y "la repetición como mecanismo estructural de generación de textos" (44). 
como cada uno pueda; y, por último, alude a un "yo que ando", alusión al pedaleo en bicicleta que ella realiza todos los días ida y vuelta a su trabajo y que marca la movilización precaria en la búsqueda de sí misma.

El Traidor considera que Patria le ha robado ese nombre extraño y sugerente, gancho para los escritores y piensa que ella es una espía, una enemiga que le quiere secar el cerebro con brujerías. Yocandra le señala que se va que ella sólo pensó que acostarse con él "sería romántico, distinto, como en las novelas" y que no se preocupara que mañana volvería a recuperar su nombre. Solo así el Traidor le permite entrar a su madriguera, señalándonos Yocandra que no hizo esto por deseo y mucho menos por amor, sino nada más que por ir a la contraria.

El Capítulo 4 "El Traidor" es motivado por una pregunta que se hace Yocandra: "Cómo conocí al Traidor? y responde señalando que ella y el Traidor se conocen bajo un aguacero torrencial, en el cual él la estudia "como una fiera a su presa" y "con unos dientes que hubieran querido volar para marcar su dura carne" y ella estaba ahí, "lista para sus mordiscos, un ser para traicionar". Agregando que nunca la vio bella, "pero sí víctima, y eso era lo que él buscaba, lo que busca" (60).

El Traidor persiguió a esta "niña hecha de lluvia" y averiguó casi todo de su vida y ella por fin acudió una noche a su cuarto, ubicado en "el solar de los intelectuales". En este lugar "malvivían pintores, artesanos, escritores, músicos, periodistas, arquitectos, ingenieros, actores y mucha chusma", entre esta última: delincuentes, proxenetas y traficantes de divisas y drogas. Esto determina que la parcela del mundo que elige el narrador para formar su mundo narrado sea el mundo de los intelectuales, ya que todos los personajes de la novela, tanto la madre de Patria, como sus amantes y amigos son intelectuales y el único que viene de la zafra es su Padre. Esa noche que Patria visita al Traidor, este se entera de su nombre y ella vuelve al día siguiente "con el nombre cambiado, con la vida cambiada" y en este momento el Traidor le pregunta si es virgen y Yocandra le responde que sí, aunque "era señorita por la vagina, pero no por otros c-anal-es", debido a que en la escuela, ella esperaba que oscureciera para restregarse en el 
muro del Castillo de la Fuerza con un ex-preso político de cincuenta años, concluyendo la protagonista que fue una aventura hermosa y que si bien algo sufrió con ella, la inició en "las lecturas diferentes".

En síntesis, Yocandra era virgen, aunque fuera formalmente y alguien tenía que desvirgarla, porque el Traidor no la aceptaba así, ya que no se atrevía a romper algo tan delicado y húmedo como el himen. Aquí el "yo" que narra se desplaza hacia el futuro, aportándonos mayor información sobre el "retrato moral" de dicho personaje y mofándose de la sensiblería de las mujeres, señalando a través de un paréntesis:

(¿Cómo iba a sospechar que mucho tiempo después, y muy a menudo, iba a desgarrar zonas más sensibles en mí: la dignidad, el alma, y toda esa mojonería tan importante para nosotras?) (41)

Así es como la jovencita asustada se transforma en un himen criminal, en "un himen dispuesto a matar el primer pene que se atravesara en su camino. Salvo el amado." Así conoce a Machoqui, un melenudo borracho y maloliente, su “destupidor” del cual nunca volvió a saber. Yocandra regresa al cuartucho del Traidor, ya que sólo quería de una manera brutal y enfermiza que ese hombre la amara. Señala:

El Traidor desvirgó mi inocencia, si hoy soy despiadada es por su culpa. Era el destinado a violar mis sueños y lo hizo cruelmente. Era el que debía mentirme y me mató a mentiras. Era el que marca, y aquí estoy cubierta de cicatrices. Él nunca lo sabrá, no está preparado. Yo lo amé como sólo puede hacerlo una adolescente. Dócil, y con la inteligencia abierta a cualquier locura. Y sus locuras las tomé demasiado en serio. Fue el primero que quise, y eso, de cierta manera, lo convierte en excepcional. (45) 
Desde ahí en adelante toda la vida de Yocandra fue un fraude, el Traidor sobornó a la escuela y le consiguió un título en la Universidad, la convirtió en empleada, aprendiz y secretaria personal. Y aunque ella nos señala que era la peor de todas estaba en la universidad gracias a la benevolencia del Traidor, pero sobre todo, gracias a su "prisión fecunda" a su servicio. Ella "obedecía por amor y él mandaba por negocio". En verdad, vivía prisionera como en un convento, mi religión era el amor y mi dios era el Traidor. En verdad yo era feliz, porque para mí aquella vida no era humillación y no tenía puntos de referencia con otros estados de felicidad. (51)

Al cabo de tres años, el Traidor le dice a Yocandra que tienen que casarse con él porque necesita una "compañera", para tomar un puesto importante que le han ofrecido en un país de Europa. A partir de ahí tendrá que acompañarlo a todas las recepciones, vestir con trajes apropiados y zapatos altos. Al respecto, el Traidor le señalaba a Yocandra: "Me gusta que andes en tacones para que resaltes. Siempre he disfrutado de que otros hombres codicien a las mujeres que he tenido. Si nadie las mira, si nadie las ambiciona, entonces también para mí pierden el encanto, dejan de gustarme" (56).

Ella entra en "la alta sociedad socialista tropical" y sale de Cuba en el Jet Set socialista europeo, conducida de la mano de un hombre famoso. Este hombre se definía como un filósofo y aunque no había escrito una palabra de filosofía, argumenta que él piensa mucho y que los hombres que piensan son filósofos. Ahora bien, el Traidor no se contentaba con ser un hombre de pensamiento, se describía como:

un hombre de acción, un Rambo del comunismo, un machista leninista. El durísimo que desde los ocho años de edad había participado en la lucha clandestina como mensajero. A los once había alfabetizado a guajiros brutísimos en la zona más intrincada de la Sierra Maestra. A los catorce casi pierde la vida y se convierte en un mártir -cualquier hospital 
podría llevar su honroso nombre- en las montañas del Escambray, en la lucha contra los bandidos. Después, por supuesto, hizo el Servicio Militar, y todas las zafras habidas y por haber. (59)

A través del paréntesis que sigue, Yocandra revierte la historia que hace del Traidor un "Guerrero Heroico", señalando: "(Sin embargo, sus manos son las de un pianista, blancas, palmas rosadas, suaves, sin una ampollita. Yo, con apenas seis escuelas al campo, tengo las manos y pies de callos)" (59).

Definitivamente, el Traidor viste, hace y nombra a Yocandra que no amaba al héroe, sino que creía amar al escritor, porque no podía amar a "ese hombre morboso que sólo lograba venirse cuando con las embestidas furibundas de su cabilla hacía sangrar su sexo". Agregando: "por eso me habitué a las pajas. Sólo a hurtadillas gozaba de un amor imaginario. De mi invención. Porque a él lo inventé yo" (60). Viajó con él al extranjero y durante cuatro años el Traidor estuvo escribiendo la que sería su obra -lastra y como guardaba celosamente el manuscrito en una caja fuerte, Yocandra comenzó a sospechar. En todo ese tiempo, nos señala:

Me iba a las ocho de la mañana, regresaba a la una de la madrugada, muerta de nostalgia, frío y hambre. Y con algo peor, o mejor, en todo caso muy grande: la duda. ¿Hasta cuándo?. En las películas, en los libros, en las casas, en las vidas de otros, el amor no era así. (62)

Yocandra consigue leer el manuscrito del Traidor y sólo encuentra en esas trescientas páginas una única frase escrita: “Todos me persiguen. No puedo escribir porque todos me persiguen". Solo encontró esa frase repetida hasta la saciedad. Entonces, se dijo NO, “un NO más grande que el de cualquier campaña política latinoamericana. No puedo seguir con este loco. Porque me está enloqueciendo, enfermando. Ya soy una psicópata” (64). Enfrentó al Traidor y 
"una vez más fue sincera" y le contó que había leído su novela y él le echó la culpa a Yocandra, diciéndole que si bien sentía que todos lo espiaban, ella lo hacía con más encono y eso le impedía escribir. Después de separarse del Traidor, Yocandra retorna a su tierra natal y se casa nuevamente, pero enviuda a los dos años. Señalándonos que esa es otra historia que no está segura que pueda contar alguna vez. Continuando con la historia del Traidor, nos señala:

Tardé mucho en enamorarme de nuevo, pero pude. ¿Olvidé? No, no olvidé, pero me dio una manía de enamorarme. Ya no soy aquella muchachita llorona y templona. Ahora me paso el día pensando en musarañas, o me voy al Malecón a venderle en dólares a las jineteras la ropa que ya no me sirve, o a cambiar azúcar por malanga, malanga por habichuela, habichuela por cebolla, cebolla por arroz, arroz por leche en polvo, leche en polvo por detergente, detergente por aspirinas, aspirinas por azúcar, y así, y así, y así... (66)

Por otro lado, el Traidor también retornó a Cuba y volvió a casarse muchas veces pero, según Yocandra, "todas las mujeres lo dejan porque se niegan a ser consideradas espías". El Traidor es un personaje que cambia sólo físicamente en la novela, ya que no varía su configuración moral, tanto es así que sigue escribiendo libros que no se publican, esto lo atribuye Yocandra al hecho que para publicar hay que esperar las donaciones de papel que hacen otros países y que haya electricidad en los talleres. Años después el Traidor la visitará y le llevará una catleya, "haciéndose el Proust”, ante lo cual Yocandra señala:

yo estaba sola. Y quise salvar la sedienta flor. Y él daba pena lo mal macho que se había puesto, flaco, calvo y encorvado, los dientes cariados y flojos. yo sabía - porque venía de verme en el espejo del cuarto- que lucía radiante con mis treinta años. Y, ¿por qué no? Lo dejé pasar. (67) 
El Capítulo 5 "La Casa de las Ex-culturas" funciona con un fuerte referente estético, consignando la iniciación sexual de Patria y profundizando la diferencia que existe entre su madre y su padre, a pesar de que ambos son igualmente golpeados por el régimen político en el que creen. En este capítulo, Yocandra vuelve a señalarnos su ritual matinal y a señalar el espacio- tiempo desde el cual está narrando, concluyendo lo siguiente:

He terminado por corroborar que la acción más importante de mi vida es despertar. Despertar del letargo impuesto por la espesa realidad. Despertar cada mañana y beber un café comprobando que el mar sigue ahí, gozándolo a través de las ventanas de mi refugio hexagonal. Despertar y beber un café y mirar el mar, ésa es mi máxima aspiración.

La protagonista ha ido convirtiendo "los menores quehaceres en derroche intolerables de tiempo" y frente al espejo piensa una eternidad y lo que antes lo hacía en segundos, en la actualidad lo hace en horas. A pesar de lo anterior siente que hoy a utilizado favorablemente el tiempo y por esa razón, se siente más segura de no haber perdido nada. Este día, Yocandra ha meditado con calma y minuciosamente en las musarañas y lleva media mañana en eso, dándole vuelta a su "telaraña". Nuevamente, el "yo" que narra utiliza el presente de la "musaraña" para ir narrando. Aquí la escritura es vista como "despertar" y esta acción es lo más importante para la voz narrativa, ya que es esto lo que le permite narrar, en esta oportunidad lo que ha pasado a sus padres.

Ya liemos hablado de la transformación en el nombre que sufre la madre de Yocandra que se llamaba Aída y ahora la gente la llama la Ida, porque "se fue al pasado, no está aquí, vive en pretérito”. La Ida sueña con el nacimiento de Yocandra y delira con su infancia, por eso cuando ve a su hija le canta, la 
acurruca como un bebé y le prepara el biberón. Yocandra nos señala: “mamá se ha ido, y no regresará". Antes de que la Aída se convirtiera en la Ida para Yocandra su mamá era "la que iba al futuro", "la que iba al porvenir". Aída había estudiado para Bachiller en Ciencias y Letras y había empezado a estudiar Historia del Arte, carrera que no pudo terminar porque triunfó la Revolución y decidió hacerse miliciana y volver al campo, a la zafra del tabaco. Se casó con el padre de Yocandra obligada, en pago de un dinero prestado y aunque éste era hermosísimo "el error era que, aunque en la cama él le gustaba un mazo a ella, no tenían nada en común, salvo las tareas contingentes de la Revolución” (81).

Formaron una familia y pasado el tiempo su padre recibió la buena noticia que el régimen le había regalado una gigantesca casa, "una joya arquitectónica”, con jardín, patio y traspatio, que había pertenecido a un escultor que se había marchado a Miami, es decir, a un "gusano". Aída muestra a su hija ese museo, descubriendo en la casa un auténtico cuadro de Wilfredo Lam, una escultura de Bellini, juegos de cuartos art nouveau de madera preciosa, lámparas Tiffany, jarrones Gallé, vajillas inglesas, alfombras persas.

Pero Patria descubre, otro tipo de belleza: la belleza del cuerpo masculino, ya que una de las habitaciones de esta casa ${ }^{6}$ estaba llena de estatuas desnudas. Uniendo el componente estético con su iniciación sexual. Al respecto, nos dice:

Mis ojos no cabían en sus órbitas al descubrir tanto esplendor. Tipos jodedoramente desnudos, inmóviles, subidos en pedestales espiaban el menor de mis movimientos. Sonrientes unos, otros demasiado circunspectos, y algunos hasta con bravura en los gestos petrificados, bailaba la danza estática del abandono. La piel rosada de un vientre

\footnotetext{
${ }^{6} \mathrm{Al}$ respecto, Gastón Bachelard nos señala en su libro La Poética del Espacio, que "la casa nos brindará a un tiempo imágenes dispersas y un cuerpo de imágenes. En ambos casos demostraremos que la imaginación aumenta los valores de la realidad. Una especie de atracción de imágenes concentra a éstas en torno de la casa" (33). Cfr. Capítulo V. "La concha" en Poética del Espacio. México: Fondo de Cultura Económica, 1965, p.33.
} 
recubría una colina de tendones, los dedos jugando con el vórtice umbilical. La brillantez de unas nalgas negras refulgían en aquella cadencia sonnolienta, la mano sólida y musculosa sostenía con firmeza una incomparable pingona prieta. (82)

En uno de estos negros desnudos, Patria experimenta su primer beso y al señalarle a su padre que había un cuarto con "una cantidad de tipos con culos y pitos al aire", se inicia en la conciencia de la culpa, ya que éste decide destruir y quemar todas las esculturas. "De inmediato reinó la hoguera. La de siempre. La que cada hombre lleva muy internamente, con el único objetivo de exterminar". Al respecto, Patria nos señala: "Por ínfimos segundos había amado una escultura. Y en ínfimos segundos también me había convertido en su delatora, su verdugo" (84).

La Casa de las ex-culturas es un antes y un después. La Cuba revolucionaria culta, promovida por los intelectuales se ha ido y no regresará, porque se ha convertido en una casa de la ex-cultura. Una Cuba donde la moral y el autoritarismo han arrasado con la belleza y con el arte. Una Cuba donde a medida que aumentó la miseria tuvo, al igual que Aída, que ir deshaciéndose de "los tesoros de la mansión". Sin embargo, el momento en que empezó a irse la Ida fue en 1967, el año en asesinaron al Che, ya que nunca pudo reponerse de la muerte de su ídolo, llamado el "Guerrillero Heroico". Por otro lado, el padre de Yocandra se convirtió en dirigente sindical y se contagió de "la enfermedad de los discursos" y al anunciar que el Este comunista iba a retirar el apoyo financiero a Cuba lo sancionaron, entonces:

Huyó a la avenida, caminó, camino como un demente. Sin siquiera darse cuenta llegó a las rejas de Mazorra, aferrándose a ellas chilló:

— ¡Sáquenme de aquí! 
- Con lo cual todos los paseantes, visitantes y enfermos, dentro y fuera del Hospital Psiquiátrico, interpretaron al pie de la letra sus palabras. Confundía el exterior con el interior de la clínica, para el los locos eran transeúntes normales, y los transeúntes eran enfermos, y las calles, en sus afiebrada histeria, devinieron celdas. No estaba muy desacertado. Fue internado de inmediato. Al cabo de seis meses lo liberaron. Los electrochoques lo habían puesto gago. (88)

Aída no aguantó este sufrimiento, cuando él salió ella lo esperaba en el umbral de otro mundo, olvidaba fechas y nombres, todo le daba risa y dormía interminablemente. Entonces Aída se convirtió, definitivamente, en la Ida y en sus alucinaciones seguía esperando al escultor que había sido el dueño de su casa para devolverle el Lam, ese "garabato del alma" del que nunca pudo deshacerse.

El capítulo 8 "Las noches del Nihilista" nos muestra al otro amante de Yocandra y comienza con una crítica literaria: "Parece que los capítulos ocho de la literatura cubana están condenados a ser pornográficos”. El narrador hace una crítica a la crítica y con ello hace consciente al lector de que construye un capítulo con un fuerte contenido erótico y anclado a una tradición literaria cubana, señalándonos:

Así se expresará el censor cuando lea estas páginas. El censor que me toca por libreta, porque cada escritor tiene un policía designado. Dictará esas palabras a la secretaria, que le tecleará el informe sobre mi novela refiriéndose para honor mío, al capítulo ocho de Paradiso, de José Lezama Lima, obra maestra de la literatura universal que, sobra puntualizar, ningún censor ha podido terminar de leer, porque se duermen, no entienden ni comino, nada de nada, ni siquiera porqué la gente dice que el capítulo ocho es pornográfico. Pero como hay que seguir dictaminando que lo es, nadie puede cuestionárselo a los censores, quienes ni siquiera conocen la diferencia entre lo erótico y lo 
pornográfico. Y por eso tampoco se dieron cuenta de no sólo el capítulo ocho, sino toda Paradiso es erótica de cabo a rabo, una de las novelas más sensuales de la literatura contemporánea. Al término de tanto silencio -censura-, por jugadas más políticas que culturales, los censores han terminado siendo más lezamianos que el Papa. (133)

El narrador al relacionar este capítulo con el capítulo 8 de José Lezama Lima se conecta con la tradición literaria cubana. Así se transforma en una "cita neobarroca" y, por lo tanto, es una distopía del pasado no sólo lo reescribe sino que también lo renueva. Así dota al presente de un significado a partir del pasado, rindiendo un homenaje al barroco latinoamericano, concretando un principio neobarroco Calabresiano: Límite y exceso $^{7}$, ya que Yocandra utiliza el contenido excesivo de la sexualidad para poner en tensión los límites políticos y culturales que le impone la sociedad autoritaria en la que vive. Al respecto, citando a Helena Araújo, Willy O. Muñoz nos señala:

sobra decir que esta represión en el discurso tiene mucho que ver con la represión en las pulsaciones sexuales impuestas por una tradición religiosa que desde hace siglos ha impedido a la mujer reconocer su libido y asumir su cuerpo. Porque decir cuerpo es decir deseo, y en la sociedad patriarcal la mujer no sobrevive sino bajo la prohibición del deseo. (Muñoz 48)

\footnotetext{
${ }^{7}$ Véase este principio neobarroco en Calabrese, en lo que dice relación con el exceso erótico como un modo canónico de encauzar y poner en crisis el sistema de valores, consistiendo técnicamente el exceso desde la oposición a la norma vigente como lugar de observación del eros, en valorar lo que produce escándalo (piedra de tropiezo) y, por lo tanto, no tendrá valor sólo por sí mismo o por lo que dice referencialmente, sino por cuanto es una provocación para superar los límites de los principios sociales comunes. Cfr. Calabrese, Omar. La Era Neobarroca. Madrid: Editorial Cátedra, 1994, p.49.
} 
El Nihilista es un Director de Cine que ha dirigido unos cuantos videoclips musicales y que ha realizado su primer largometraje de ficción. Este cineasta estuvo siete años "entre premios, interrogatorios, cárceles, autoencierros, disidencia y reintegración" y no le han exhibido comercialmente su película, porque es "postexistencialista", señalando Yocandra que "ya es bastante con la vida de sacrificio que lleva este pueblo, encojonadamente postexistencialista, para castigarlo con su propia imagen". Por lo tanto, este cineasta al devolverle la imagen al pueblo cubano, lo perturba, ya que deja en evidencia los defectos del sistema. Esto se entiende si tomamos en cuenta que en su segundo guión la historia narra un viaje de tres jóvenes de una punta a la otra del Malecón y que en el climax uno de ellos se va en una goma de camión para Miami y los demás se quedan mirando. Por lo tanto, "es un guión que habrá que re-trabajar, re- escribir, re-modelar, re-cambiar, re-tomar, re-botar. Re-primir".

Yocandra conoció al Nihilista en una Muestra de Cine Joven, él era disidente y no le permitían concluir su primera película, muy pocos lo saludaban y "pasaba entre la multitud como si fuera transparente". Yocandra estaba junto al Lince y la Gusana, también se encontraban:

el Gigante, que no aparece en esta novela porque es tan grande que se llevaría el solo todos los capítulos (además es noble, acaba de descubrir que lia heredado a uno de sus antepasados: ¡un abad francés!), el Pianista, que tampoco está aquí en estas páginas (de todos nosotros es el más lúcido, pues posee una misteriosa conexión con una voz del más allá que le aclara muchas dudas antes de meter la pata), y el Dentista, el más salsoso de nosotros, el tremendón. (Valdés 136)

Sistemáticamente, el narrador hace tomar conciencia al lector de la construcción de la novela, en este caso haciendo hincapié en tres personajes que 
dejará fuera de ella. Tres historias, tres capítulos que de haber sido incluidos hubieran convertido los nueve capítulos de los que consta la novela en doce. ${ }^{8}$

Dos años más tarde sería el Lince que llevaría al Nihilista a la casa de Yocandra, se había propuesto ayudar por todos los medios a ese joven cineasta y al mover cielo y tierra lo "volvió al reino de este mundo: limpio, desnudito, acabadito de nacer". Yocandra describe así este encuentro:

A ojo de buen cubero, supe que me iba a enamorar. No sólo porque me pasaba la vida enamorándome, es como una manía, sino porque estaba atravesando el peor y más solitario de los instantes a causa de tanta efímera compañía, y necesitaba a alguien inteligente, enigmático. Necesitaba del big love, morirme de amor, vivirme de amor, descojonarme. Un tipo que acabara conmigo y yo con él. Que nos acabáramos los dos. Y que comprendiera que yo no soy fácil, que estoy medio o absolutamente arrebaté. Hoy amo, pero mañana no soporto, y ésas majaderías no hay muchos tipos que estén dispuestos a aguantarlas. Tampoco tenía mucha cabeza para los mariditos. Yo andaba buscando el amante eterno. Y creo, a lo mejor me equivoco, que lo atrapé. (139)

El primer beso que Yocandra le da al Nihilista es como ese primer beso que ella le dio a la escultura de rizos sobre la frente cuando era adolescente: "con la lengüita ondulante, como uno imagina en la infancia que se besan los adultos". Este beso se extiende a todo el cuerpo de Yocandra y ella va construyendo el cuerpo del Nihilista con un sentido estético, señalándonos: Este hombre se me antojaba una exquisita obra de arte por fuera y por dentro. Porque es tierno,

\footnotetext{
${ }^{8}$ Es interesante constatar que la "musaraña" es el mamífero más pequeño del reino animal y que es un devorador, ya que puede llegar a consumir diez veces más que su peso. Su cuerpo mide entre 3 y $9 \mathrm{~cm}$., llegando a medir 12 si tomamos en cuenta su cola.
} 
paciente y pacífico. Su voz nunca se altera en lo más mínimo. Es mi amante, no mi verdugo". (141)

Yocandra no le cuenta al Nihilista que esa noche ha recibido una carta de la Gusana y un llamado del Lince, no quiere entristecerlo. Señalando: "bastante tenemos connuestras pobres ilusiones y nuestros proyectos truncos. Mejor lo dejo soñar con su película, con sus obsesiones" (152).

Los capítulos 6 y 7 configuran las amistades ausentes de Yocandra: la Gusana y el Lince. La Gusana es una geógrafa cubana que vive en Madrid que se comunica con Yoqui (así llama a Yocandra) por medio de una carta y el Lince es un Licenciado de Historia del Arte que ha escapado en una balsa artesanal a Estados Unidos y realiza una llamada telefónica para contactarse con Yocandra. Carta y llamada son recibidas en ese día clave donde la vida le ha caído a la protagonista de golpe, el mismo día donde ella comienza a escribir.

Ese día el "yo" que narra parece adelantarse al recibimiento de la carta de la Gusana y empieza a evocar a su "gusanita querida" desde el momento que pone los pies en su bicicleta. Señalándonos:

Te conocí en los viajes al Pedagógico, cuando yo iba a sobornar al Decano. Tú estudiabas Geografía, enseguida nos hicimos socias a pesar de la desconfianza del Traidor, que no te podía ver ni en pintura. Yo me escapaba y te iba a buscar, tú pedías dos bicicletas prestadas y nos íbamos pedaleando hasta el muro del Malecón. Allí hablábamos y nos burlábamos del mundo. En aquella época montar bicicleta era cosa de putas, de guaricandillas, y la gente nos insultaba. (94)

Yocandra hace evidente la complicidad que tiene con la Gusana, al señalar: "En eso de los pedales también fuimos precursoras". Esto se entiende si consideramos que la Gusana había sido una de las primeras "jineteras" cubanas y, por lo tanto, había sido precursora en otras áreas de la vida. Yocandra no quiere 
detenerse en el presente, en esa "Habana triste, desvencijada, hecha leña", ya que no quiere ser testigo del hambre del pueblo cubano, porque si bien es cierto que en toda la América Latina se pasa hambre, nos señala que ellos no hicieron la Revolución.

El narrador se pregunta dónde está ese mundo mejor que estaban construyendo, que no lo ve. Por eso evoca un pasado cubano, interrogando a la Gusana si se acuerda: de las cafeterías, de los tallarines, de los helados, de las librerías, de la luz, de todo lo que no hay ahora en Cuba. Afirmando: "Sobrevivimos con el estómago encharcado o cerrado por reparación. Nada existe. Solo el Partido es inmortal" (97).

La carta de la Gusana va dando cuenta de cómo ésta se ha ido traicionando a sí misma. Primero, renunció al amor del Lince y se casó por interés con un viejo gordo español para salir de la isla, porque aunque el Lince era el amor de su vida, no estaba dispuesta a compartir un porvenir incierto con un microbrigadista que tuvo que meterse a albañil y que no tenía vivienda y dormía en balsas plásticas debajo de las escaleras, al contrario del "Dinosaurio gallego" que la invitaba a las piscinas de los hoteles y le regalaba ropa con etiquetas. Debido a lo anterior, Yocandra señala "tu existencia, gusanita mía, es como un cabaret exento de rumba. Un calvario" (109).

Por otro lado, la Gusana se ha vuelto consumista y superficial. Esto se puede apreciar cuando le cuenta a Yocandra:

Sí, claro que compro todos los días un jaberío de naderías. Aquí comprar es un vicio, y yo soy una viciosa, ¡tengo una sangre para los vicios! Y la televisión corrompe. En eso les doy la razón a los hablacáscaras de allá, la propaganda es realmente enemiga, pero enemiga del bolsillo. Oye, que te van envolviendo y enloqueciéndote: hoy una marca de champú, mañana el acondicionador y pasado mañana la cera depiladora, y los helados, los dulces, el jabón éste y el otro y el de más allá con leche de 
cabra y glicerina, y el perfume de mañana y el de tarde y el de noche. (105)

Sin embargo, el tema principal de la carta de la Gusana es hacer llegar a Yocandra las últimas noticias sobre el Lince, teniendo en cuenta que éste había escapado de Cuba en una balsa artesanal hace justo un mes La Gusana le cuenta que:

Naufragaron y sus compañeros de viaje desaparecieron en el océano. Sólo él sobrevivió. Fue hallado por una embarcación americana: Los despojos de la balsa navegaban a la deriva, su cuerpo exhausto quedó enredado por casualidad, fuertemente amarrado con una soga a un palo. El caso es que llegó y se ha recuperado perfectamente, al menos eso me dijo. Me llamó por teléfono, fue una gran sorpresa. Al mismo tiempo tuve que regañarlo, ¡qué locura, dios!, pudo haber muerto como los otros. Lo noté confundido, asombrosamente triste dado su carácter optimista. Pero enérgico, con ese vigor, esa fortaleza que sólo da el haber rozado la boca de la muerte, su mordida fatal. (108)

Al saber Yocandra este hecho, siente que "se ha cerrado el ciclo" y que los han condenado "a vivir desperdigados por el mundo, al peligro constante, al dolor agudísimo en ese hondo precipicio de las conciencias, a la renuncia de nosotros mismos, de nuestros sueños" (Valdés 109). El narrador alude al sentido de la historia, al aseverar:

Somos culpables de nacimiento, cada acción nuestra afloja la soga que dejará caer la guillotina que tumbará nuestras cabezas sobre la paja de la historia. Albergo la esperanza de volver a verlos, capullitos míos, y aparecerán flamantes, revoloteando, transformados en mariposas. Y 
quizás de mi renazcan pétalos, como de una rosa que no ha sido arrancada. (112)

El capítulo 7 "El Lince", no se entiende sin el flash-back que encontramos en el Capítulo anterior, en el que utilizando una técnica cinematográfica el "yo" que narra a través de una analepsis ${ }^{9}$ cuenta como el Lince con una "suerte del carajo" se ganó miles de dólares en un concurso de pintura en Japón y que luego de instalar su casa, apareció el gobierno y le decomisó todo, acusándolo de nuevo rico. Tuvo un juicio y fue declarado culpable y poco antes que fuera encarcelado, apareció un ministro japonés que había adquirido el cuadro premiado y que quería ver a su creador. Esto impidió que fuera a la cárcel, pero no que terminara en la Rampa sin una escalera donde pasar la noche.

El Lince “era distinto, raro, un foco de atención”. Al respecto, Yocandra nos señala que el Lince se cansó de ser obediente. Agregando a través de un paréntesis:

(Somos los monjes de una obediencia ciega y, como en la Inquisición, cargamos penosamente con cadáveres achicharrados. Nos doblega una jiba torturante y sangrienta. A la generación de los felices le pesa desgarradoramente en las espaldas demasiada gloria. Nunca podremos erguirnos totalmente por culpa de los fusilamientos. A pesar de que nos temblaban las barbillas, seguíamos creyendo en las editoriales de Granma. Y las motivaciones, en ciertos casos, fueron oscuras). (114)

\footnotetext{
9 Luz Aurora Pimentel, citando a Genette señala que en la analepsis se interrumpe el relato en curso para referir un acontecimiento que, en el tiempo diegético tuvo lugar antes del punto en el que ahora ha de inscribirse en el discurso narrativo (flash-back, según la terminología cinematográfica) Cfr. Relato en Perspectiva. México: Siglo XXI Editores, 1998, p. 44.
} 
Ya en la Universidad, el Lince había sido perseguido por llevar melena, boina y pantalones tubito. Se salvó de que lo echaran, porque acababa de defender magistralmente su tesis y sólo le restaba recibir el diploma. Ya desde entonces "sospechó que estaba predestinado para la fuga". El Lince fue enviado a Moa para realizar su servicio social, aquí debía construir la Casa de la Cultura. En este lugar no había nada de nada, ni un círculo de interés de poesía o de artes plásticas y además era el terreno más yermo de todo el planeta. Yocandra haciendo una alegoría de la revolución nos señala:

Pero el Lince era mucho Lince. Astuto, era la amenaza en dos patas. ¿Y qué hizo?. No bien hubo arribado, sin sacudirse el polvo del camino, igualito que Martí frente a la estatua de Bolívar, se dirigió al corazón de Moa y sacó a todos los habitantes de las camas recitando un poema de Cavafis a través de un altoparlante. Los vecinos abrieron las puertas entre boquiabiertos y somnolientos, bostezaban sonoramente, tosían, carraspeaban, las mujeres restregaban sus ojos limpiando las legañas sin la menor coquetería. Se fueron acercando a medida que el poema fue tomando aliento y rodearon al Lince. Ya no lo observaban extrañados, sonreían tímidos. (114)

Este texto es un fragmento ${ }^{10}$ del poema Esperando a los bárbaros $^{11} \mathrm{de}$ Cavafis y que a medida que va siendo recitado por el Lince, los vecinos ven

10 Nos parece necesario retomar lo que Omar Calabrese señala que "el fragmento, aún perteneciendo a un entero precedente, no contempla su presencia para ser definido; más bien, el entero está in absentia y por lo tanto, desde un punto de vista discursivo, la operación de la ruptura se ha introducido en un discurso histórico y no en un discurso con huellas de la enunciación". Véase el principio neobarroco Calabresiano: Detalle y fragmento, p. 54.

${ }^{11}$ Es interesante que Ornar Calabrese al abordar el principio neobarroco: Límite y Exceso, señale que toda sociedad tacha de excesivo lo que no puede o no quiere absorber y, por lo tanto, que todo orden produce un autoaislamiento y define, intimidándolo, todo exceso. Entonces el enemigo se hace enemigo cultural, "bárbaro", una gran invención de las civilizaciones clásicas. Sin embargo, en las sociedades barrocas sucede a la inversa, el exceso es asumido al interior del sistema que intenta desestabilizar. Revisar Calabrese, p.49. 
entendiendo el texto, "o interpretándolo, cosa mucho más sutil". Esto muestra un criterio de inclusión, ya que los moenses permiten que el Lince y la cultura, específicamente, la poesía se integren a su sociedad, dejándose persuadir en la construcción de la Casa de la Cultura. Con esto el Lince se hizo famoso y en todas partes del país se empezó a hablar del milagro cultural producido por el frenético activista. Nos señala Yocandra que el Lince "vivía en total trance de identidad artística y política" y "en él se manifestaba en todo esplendor el erótico sentimiento de la inmortalidad del héroe". Entonces para que repitiera la hazaña lo trasladaron al lejano y desolado pueblito de Mamoncillo. Lo tramitaron tanto para la construcción de una casa que se dio por vencido y pidió el traslado para diseñador de una revista literaria, la misma en la que al tiempo después le conseguiría trabajo a Yocandra. Desde ese momento nos señala Yocandra "nos hicimos socios, hermanos, aseres, moninas". Después de trabajar juntos y ayudarle en la decoración de su apartamento Yocandra lo vio un día antes de ser detenido y no lo vio más, hasta esa noche en que tras leer la carta de la Gusana, recibe su llamada telefónica desde Miami.

Con esta llamada se actualiza la presencia del Lince en la vida de Yocandra, trayendo como consecuencia que esta se decida a escribir y construya la novela. Al respecto, Remo Bodei nos señala:

En la cultura barroca, el lince se convierte en alegoría de la agudeza, de una forma de conocimiento que penetra las apariencias, reduce las distorsiones y los aturdimientos que en el juicio provocan las pasiones, descubre y descifra los más ocultos significados de las cosas, procura eliminar las ambigüedades, analizando los comportamientos humanos y los fenómenos naturales. En cambio la jibia es el emblema de los artificios del camuflaje, de ocultación, de encubrimiento y de manipulación de las informaciones que pretenden confundir los límites entre "verdad" y "mentira", "realidad" y "apariencia", actitud comunicativa y actitud estratégica. (Bodei 59) 
A través de la llamada, Yocandra comienza a aconsejar al Lince acerca del exilio y a pesar que le cuesta hablar, ya que es la primera vez que se le va "un ángel para el Norte, en el sentido rilkeano de que todo ángel es un demonio", le señala que "La Habana, Ciudad Mortaja, estará terriblemente agonizante por haber perdido a otro habanero ilustre". Aquí nos damos cuenta que el narrador construye una ciudad verbal y, por lo tanto, "impone su propia mitología de la ciudad al lector" (Valdés 32), ya que La Habana será la Ciudad- Laboratorio, la Ciudad-Experimento y por último, la Ciudad Mortaja. Con esto el discurso narrativo se opone al mito compartido de La Habana: Ciudad Libertad.

Yocandra le aconseja al Lince que tenga paciencia, que no trate de llegar y ser y que no se deje arrastrar por el síndrome del cubano, de la "jodida nostalgia" y que tampoco la niegue sino que la dosifique pero sin obsesiones que sea "alimento espiritual y no veneno". Agregando que lo verdadero es "no cagarse el alma con nimiedades". Yocandra confirma esta cercanía que el Lince le ha provocado, señalándole: “Estamos muy cerca, muy cerca. Mira, Lince, estás aquí: en la yema de mis dedos, te me sales por las uñas y me entras por cada ínfima porción de la piel". Termina aconsejándole que no olvide lo principal y que no se ahogue en ese mar separador que el mismo ha cruzado y donde vio morir a otros hombres, igual que él, aterrorizados y le profetiza la siguiente imagen: "serás un lúcido ladrillo para ese puente de asfalto humano". Y aunque un exiliado tenga hasta la tumba prohibida, "la tierra está donde él esté. La tierra es él con su verdad" (125).

El Lince le dice a Yocandra que tiene razón que él se fue de la isla porque estaba harto de repasar la distribución de alimentos y los apagones de luz, publicados "en el único periódico de dos páginas, y que nunca corresponde a la verdad". Señalando que su cerebro se iba secando y lo de la prisión lo había perjudicado, aunque "a nivel psicológico no era muy diferente que en la calle". Entonces, esa noche en que los falsos pescadores le piden que elija entre quedarse o irse, y aunque "uno nunca ha conocido la importancia del verbo elegir", sin 
decidirlo decidió irse porque no tenía nada que hacer. Posteriormente, el Lince le relata a Yocandra como fue esa experiencia, señalando que no puede describir con exactitud ese instante de la desaparición física de sus compañeros de viaje, ya que “el lenguaje, las palabras, son como una amnesia caótica”, por lo tanto, sólo puede contarlo "siguiendo la inercia que ha quedado latiendo en la memoria". Ahora camina por las calles de Miami y se pregunta si su existencia será un sueño o realmente estará vivo y aunque quisiera olvidar, ser cruel y olvidar, al mismo tiempo una energía hondísima enerva sus sentidos. El Lince le señala a Yocandra:

Sufro cada minuto por no poder contar mi experiencia, pero te digo que hasta creo que me acostumbraré. Ya ni tiemblo. Aunque sí lloro. Los espacios son inmensos para la melancolía. Atenderé, de todas formas tus consejos. Aquí he encontrado viejos amigos que han sido muy solidarios en todos los sentidos, pero no estás tú ni la Gusana, ni oíros tantos con los cuales cada vez sueño con más intensidad. Vivir en el exilio aguza el estado onírico. Tengo varias ofertas de trabajo para cuando legalice mi situación. Por lo pronto trabajo en negro y gano satisfactoriamente. Al menos ya alquilé un sencillo apartamento. ¿Sabes una cosa? Lo busqué con vista a tu buhardilla hexagonal. Cada mañana me asomo a la terraza y te soplo besos. Espero que a partir de ahora hagas lo propio. (129)

El Lince, junto con la Gusana se transforman en los personajes que desde el exterior motivan a Yocandra a escribir un libro, pero el Lince al arrendarse este departamento y soplarle besos a través de la ventana, se transforma en la inspiración literaria y la lucidez que necesitará la protagonista para ver al Lince y todo lo demás "en ese sitio imaginario que tanto nos pertenece, incluso cuando se nos escapa, ese sitio que tanto nos duele: la vida" (155).

En el Capítulo 9 "Y yo lo tenía en un altar", Yocandra, estando con el Nihilista recibe la visita no anunciada del Traidor, éste la besa en las mejillas para que el Nihilista no sospeche, señalándonos Yocandra: "Porque el Traidor está al 
tanto de mi historia con el joven, y la acepta. Él sabe que lo mío es pura vendetta". El Nihilista, si bien no ignora sus encuentros con el Traidor cree que sigue dándole un tratamiento amistoso a su primer "marido psiquiátrico". Así, nos señala Yocandra, "alterno las mentiras". El Traidor ha ido a casa de ella a leer un librito de Lyotard, el filósofo francés del posmodernismo, ya que en su casa cortaron la luz. Yocandra los presenta con los nombres que ella les ha puesto y se dirige al baño y desde ahi observa como el Traidor se dirige al Nihilista y empieza su discurso insultante. Yocandra nos señala: "Yo los espío a través del filo de las ventanas, una que da a la sala y otra a la cocina. Todo narrador, además, es ubicuo" (158). Es decir, todo narrador tiene un punto de vista, pero a la vez está presente a un mismo tiempo en todos lados. Mientras ella los observa el traidor le señala al Nihilista que él es "el que le enseñó todo lo que ella conoce de este mundo", pero el Nihilista le dice que no exagere que otros también le han dado algo y que ella ha aprendido por su parte, "Es inteligente Nosotros le debemos mucho también". Sin embargo, el Traidor piensa que él no le debe nada a Yocandra, porque él siempre ha sido brillante y se presenta ante el Nihilista como un filósofo y un novelista.

El Traidor interroga a Yocandra por el origen de su nombre, esta sabe que si responde "sería como remover en la mierda, sacar patéticas excrecencias a relucir". Sería, nos señala Yocandra como "opinar de él como nunca lo había hecho, ni conmigo misma delante de un espejo", pero a pesar de eso sus labios "se mueven mecánicos":

No creas que te guardo rencor por los tarros que me pegaste, ya eso no tiene ninguna importancia para nadie. No pienses que tengo alguna idea fija contigo, o que hago esto o lo otro para que me debas algo. Lo que hago, lo hago por humanidad, porque la venganza también es humana. Podría haberte botado y te dije que te quedaras. Así que no te hagas ilusiones, ese apodo en nada tiene que ver con alguna pasión personal. No es porque me hayas traicionado, por lo que ahora te nombro así. Sé 
que has cambiado mucho en tus posiciones políticas: si antes eras un comecandela, hoy esquivas cualquier compromiso con el régimen. [... ] Pero tampoco es por esa razón por la cual te puse Traidor. ¿No te das cuenta, no te miras en un espejo? ¿Cuándo vas a dejar de traicionarte a ti mismo? ¿Cuándo acabarás de ser coherente con tus propios pensamientos? ¿Cuándo dejarás de inventarte a ti mismo, haciendo creer que escribes un libro?. Si lo que haces es como una tarea de la escuela, una penitencia: seiscientas páginas de líneas con un fragmento repetido: "Soy escritor. Todos me persiguen y no escribo. Soy escritor". La letanía impresa hasta el convencimiento de lo contrario. Tú vives en la traición. Eres el traidor de ti mismo. Necesitas traicionar las pequeñas cosas de la vida. (161)

Yocandra decide enfrentar al Traidor y romper su pasividad. Decide llorar, señalándonos: "Lloro porque hoy todo me sucede de sopetón, a mí que nunca me pasa nada, que siempre hago lo mismo: pedalear y pensar en las musarañas". Siente que se está muriendo y agrega:

Nací marcada por el deber trascendental. Debí ser fiel a mis progenitores. Debí ser fiel a la patria. Debí ser fiel a la escuela. Debí ser fiel a las organizaciones de masas y a las otras. Debí ser fiel a los símbolos patrios. Debí ser fiel a mis "compañeros" (la palabra "amiga" fue empobrecida, eliminada). Debí ser fiel a mi esposo, digo, a mi "compañero". Debí ser fiel a todo lo que no me fue fiel. Por exceso o por defecto. Queridos paternalistas, miren como me mata la fidelidad. Lloro infiel, y ésa es mi cobarde prueba de coraje. Saber que lloro porque no creo en nada. Ni en ti, Nihilista, que me estudias con las pupilas secas, y no mueves ni un dedo para impedir mi histeria. (162) 
Por lo tanto, Yocandra llama así a su primer amante porque se ha traicionado a sí mismo, anticipando que a pesar que ella debió ser fiel a todo también terminó traicionándose y no creyendo en nada y por lo tanto la protagonista está consciente que hoy le ha caído encima toda la vida de golpe: la infancia, sus padres, la Gusana, el Lince, el Traidor, el Nihilista, la oficina, el mar y el país. Y se hace necesaria la pregunta existencial:

¿Cómo dejar de ser yo? Yo con mi nada a cuestas, mis minucias, mis pobrecitas cagaditas cotidianas. Para ser sincera y no engañar a nadie, mucho menos a mí, podría quitarme toda esa cagadera de la cabeza y dedicarme a mi otro yo ficticio. Sacar la careta reservada para la supervivencia: yo, jefa de redacción de un prestigiosa revista literaria. [...] ¡Pero ésa no es mi vida, no soy yo! Sin embargo, así vives. Así te manifiestas. Es tu retrato hablado. (165)

En esta cita se puede apreciar el "yo" de la escritura, el "yo" narrador y el "yo" personaje que al ser careta de la sobrevivencia se transforma en un no-yo, sin embargo el narrador en segunda persona señala que así se manifiesta la voz narrativa. Mientras Yocandra reflexiona los dos amantes de Yocandra terminan jugando ajedrez, doblados sobre reinas, reyes, alfiles, torres y caballos y ella exclama: “¡Cómo ha diseñado de biensus entretenimientos el hombre! ¡A su imagen y semejanza!", entonces prefiere escabulllirse a su celda o refugio hexagonal que posee:

tres ventanas a través de las cuales el mar se ve diferente .En la de la derecha las olas van y vienen gigantescas, encrespadas, furibundas. En la del medio el mar es un plato, azul brillante, con esa estela surrealista de iluminación tropical. En la ventana izquierda el mar aparece negro, sobre el oleaje flotan estrellas. Sin embargo, en cualquiera de las tres espejean 
la luna y el sol a la vez, y anochece y amanece intermitente, como en los viceoclips, a todo meter. ${ }^{12}$

En el gráfico "La Musaraña Barroca", estas tres ventanas están representadas por una línea roja, ya que a través de estos tres capítulos la protagonista ve su "nada cotidiana" y comienza a describirla. Sin embargo, Yocandra no está dispuesta en ocupar la noche en "gastar neuronas", prefiere ir a botar la basura, la "nada cagada" y estando en la calle, junto a los tanques que se desbordan se encuentra con cinco o seis viejas, de las cuales la más anciana comenta "con inesperado tono de arrepentimiento: ¡Y Yo que lo tenía en un altar!", de inmediato las demás mujeres, armadas de palos, interrogan y amenazan a la anciana, esta se retira silbando La Internacional para evitar todo tipo de sospecha y las "robustas féminas", cuyo trabajo consiste en "vigilar y golpear", se quedan registrando todos los papeles de la basura. Yocandra sube arrastrando los pies y con ellos arrastra su miedo, señalándonos "Es la primera vez que siento un miedo desquiciado. Espero la puñalada trapera, el venenazo, la escupida de fuego, el mazazo en el cráneo. Pero no llega. Nunca se presenta de frente, directo".Busca cualquier pretexto para no seguir pensando más, no quiere comprometerse en algo que no sabe si va a poder hacer. No sabe si tendrá ovarios para describir la nada que es su todo, pero ahí está la Gusana, exigiéndole un best-seller y no está el Lince para aprobar la novela, "afirmando que es genial, que habrá que publicarla al precio de la vida". Así, con el miedo más grande del mundo besa el cristal de la ventana del medio con "la certeza de que el Lince estará haciendo lo mismo ahí enfrente", invoca a sus orishas y nos señala:

Por eso chachareo y chachareo. Para impedirme comenzar. Para evitarme iniciar la frase. Para autocensurar las palabras que, como unas locas, unas putas, unas hadas, unas diosas, explotan desaforadas con la tinta de la

\footnotetext{
${ }^{12}$ Véase el gráfico "La Musaraña Barroca" que inicia este artículo.
} 
pluma que mis dedos aprietan. Porque hay amigos muy grandes que murieron, otros que se fueron y otros que se quedaron. Todos aquí, dentro de mí. Dentro de las palabras que no sé más si soy yo que las escribe. O si son ellas las que me escriben a mí:

Ella viene de una isla que quiso construir el paraíso...

En esta cita podemos apreciar como la trama de la LNC se convierte en una musaraña que le permite a la voz narrativa configurar una situación narrativa en la que el lector asiste al enfrentamiento entre la escritura y la nada. Yocandra cree en la historia, pero no en la historia verdadera, por eso opta por un "chachareo" que le permite ocultar su historia personal, volviendo a un lenguaje mítico-poético, haciéndose patente la decepción de la escritura.

Estamos en presencia de una narración repetitiva ${ }^{13}$, y además de una "estética de la repetición" (Calabrese 45) ya que el final de la novela es puesto también al comienzo del Capítulo 1, intensificando la ilusión de circularidad temporal y confundiendo al lector que no sabe si ese acto narrativo ocurre antes o después en la serie cronológica que enmarca a estos dos actos narrativos, obligándolo a volver a empezar la novela y a quedar entrampado también en ese círculo temporal donde presente, pasado y futuro se igualan. Sin embargo, el tiempo del discurso es un día de "nada cotidiana", un presente desde el cual Yocandra recordará su pasado y construirá su futuro.

\section{Bibliografía}

Bachelard, Gastón. Capítulo V. "La concha", en la Poética del Espacio. México: Fondo de Cultura Económica, 1965.

${ }^{13}$ Estamos ante una narración repetitiva "cuando un acontecimiento sucede una sola vez en la historia pero es narrado más de una vez". Luz Aurora Pimentel, p.55 
CATEDRAL Tomada: Revista de crítica literaria latinoamericana / Journal of Latin American Literary Criticism Musaraña barroca: análisis textual de La nada cotidiana de Zoé Valdés.

Bal, Mieke. Teoría de la narrativa (Una introducción a la narratología), Madrid: Ediciones Cátedra, 1985.

Barthes, Roland ¿Por dónde empezar? Barcelona: Tusquet Editor, 1974.

Calabrese, Ornar. La Era Neobarroca. Madrid: Editorial Cátedra, 1994.

Montecinos, Sonia. "Testimonio y Mujer: algunas reflexiones críticas", en La

Invención de la Memoria de Jorge Narvaez, Santiago de Chile: Pehuén Editores, 1988.

Muñoz, Willy O. Polifonía de la marginalidad. Santiago de Chile: Editorial Cuarto Propio, 1999.

Pelegrin, Benito. "Del fragmento al sueño de la totalidad. Entre dos infinitos, el aforismo", en Barroco y Neobarroco, Madrid: Visor, Círculo de Bellas Artes, 1993.

Pimentel, Luz Aurora Relato en Perspectiva. México: Siglo XXI Editores, 1998.

Savater, Fernando. Heterodoxia y Contracultura. Barcelona: Montesinos Editor, 1989.

Valdés, Zoé. La Nadia Cotidiana. Buenos Aires: Emecé Editores, 1996.

Vitier, Cintio. "Un libro maravilloso", en Recopilación de textos sobre José Lezama Lima, edición de Pedro Sim n, La Habana: Casa de las Américas, Serie Valoración Múltiple, 1970. 